\begin{tabular}{c} 
International Journal of Engineering \& Technology, 7 (3)(2018) 977-990 \\
International Journal of Engineering \& Technology \\
SPC \\
Website: $\begin{array}{c}\text { www.sciencepubco.com/index.php/IJET } \\
\text { doi: } 10.14419 / \text { ijet.v7i3.9421 } \\
\text { Research paper }\end{array}$ \\
\hline
\end{tabular}

\title{
Basic design of a cooling system for nylon 6, 6 process
}

\author{
Karthik Silaipillayarputhur Ph. D*, Nasser Al Mulhim, Abdullah Al Mulhim, \\ Mohammed Arfaj, Ahmed Al Naim \\ Dept. of Mechanical Engineering, King Faisal University, Al Ahsa, Saudi Arabia \\ *Corresponding author E-mail: ksilai@kfu.edu.sa
}

\begin{abstract}
The project concentrates on the basic design of a cooling system for rapidly cooling nylon 6,6 polymer fibers using cold air. The ambient air after pre-treatment in the air-washer is available at $72^{\circ} \mathrm{F}$ all year round. Based on the company's throughput, it is required to supply (quench) air at $58^{\circ} \mathrm{F}$. Nylon 6, 6 polymer after thorough polymerization is distributed through 16 quench cabinets and each quench cabinet requires approximately $530 \mathrm{ft} 3 / \mathrm{min}$ (cubic feet per minute, CFM) of air. The project concentrates on the basic design of a cooling system wherein air at the required mass flow rate is supplied at $58^{\circ} \mathrm{F}$ for the quenching process. A basic design of the refrigeration cycle and heat exchangers were considered in this work. In the development of the basic design for heat exchanger, performance charts were developed. Performance charts describe the performance of the heat exchanger in terms of fundamental dimensionless parameters. Using performance charts it was clearly seen that increasing the number of transfer units (NTU) doesn't necessarily increase the rate of heat transfer. Increasing the NTU beyond an optimum value is pointless and increases the capital cost of the heat exchanger. The preliminary design involves selection of appropriate NTU and capacity rate ratio for the heat exchanger. From the capacity rate ratio and NTU, it is fairly straight forward to extrapolate the detailed design for the heat exchanger. A cooling system model was developed for the design process and for the simulation of the cooling system.
\end{abstract}

Keywords: Cooling System Design; Preliminary Heat Exchanger Design; Performance Charts.

\section{Introduction}

Use of cooling systems are prevalent in all process and manufacturing industries for addressing various cooling requirements in the plant. Cooling requirements can be numerous; it can be for equipment cooling, or for air conditioning in buildings, or for the industrial process itself. Likewise, all large commercial buildings employ cooling systems for providing the required air conditioning in the buildings. It must be recognized that in large scale refrigeration systems, where substantial amount of cooling is required, a secondary refrigerant such as chilled water is employed. This is because in process plants and in commercial air conditioning systems, refrigeration systems are centrally located in one place and it is difficult to pipe the refrigerant to circulate over large distances. Therefore, a secondary refrigerant such as chilled water is often employed. Herein, the chilled water comes in contact with the medium that requires cooling. It is easy to circulate water over large distances. Leakages from water lines can be tolerated and water is non corrosive. Above all, water has high specific heat value that enables it to remove large quantities of heat. Therefore, chilled water systems are widely used in large-scale refrigeration systems.

This project considers the development for a chilled water cooling system for a nylon 6,6 production unit. Nylon 6,6 polymers are widely used in fabrics, providing re-enforcement strength for car tires, plane tires, belts, ropes, etc. During the production of nylon 6, 6 polymer it is required to quench (rapidly cool) highly viscous polymer using pre-treated environmental air. Quenching process solidifies the viscous nylon 6,6 polymer into fine threads before they are drawn into yarn for varying properties and requirements.

The environmental air after pretreatment in an air washer is available at $72^{\circ} \mathrm{F}$ at all times. The flow rate of air is $530 \mathrm{CFM}$ per quench cabinet. There are 16 quench cabinets and therefore the requirement is to cool $8480 \mathrm{CFM}$ of air from $72^{\circ} \mathrm{F}$ to $58^{\circ} \mathrm{F}$. Abundant space is available to erect the cooling system. Pre-existing air ducts connect the air washer with the quench cabinets. This design project aims in developing a basic integrated cooling system such that 8480 CFM of air is cooled from $72^{\circ} \mathrm{F}$ to $58^{\circ} \mathrm{F}$. As we can readily observe, this requires the development of a cross flow heat exchanger such that air exchanges heat with a cooling medium, presumably, chilled water. Likewise, it is essential for the cooling medium (chilled water) to exchange heat with a refrigeration system such as a chiller. Therefore, it is required to develop a refrigeration cycle and also a pumping system to circulate chilled water through the cross flow heat exchanger and through the refrigeration (chiller) unit. For brevity, the development of the pumping system is not discussed in this paper.

The major components of a vapor compression refrigeration cycle consists of an evaporator, a condenser, a compressor and a throttling device. This work shall also concentrate on the basic development of an evaporator and condenser equipment. Most chillers have water cooled condensers as water provides better heat transfer as compared to air and enhances the life span of the chiller unit. However, a water-cooled condenser will require an additional design of a cooling water circuit for the condenser equipment. For brevity, the design of a suitable pumping system for the cooling water and a selection of a cooling tower are not discussed herein.

There are numerous references available in the literature pertaining to heat exchanger performance modeling, and only the most pertinent are discussed. Kays and London [1] and Rohsenow [2] described both the logarithmic mean temperature difference and the $\varepsilon$-NTU methods in order to size and predict the performance of a 
heat exchanger. Domingos [3] presented a general method of calculating overall performance and intermediate temperatures of complex crossflow heat exchangers using the concept of effectiveness and a local energy balance. Pignotti and Shah [4] and Shah and Pignotti [5] discussed the tools developed previously (such as Domingos' method, the Pignotti chain rule, etc.,) to determine the $\varepsilon$-NTU relationship for highly complex heat exchanger flow arrangements. As compared with the present investigation, these studies pertained to quite different geometries such as cross flow and shell and tube heat exchangers. Furthermore, they did not address the design of optimal heat exchangers, which achieve the required task at the lowest cost while satisfying imposed constraints. Mott and Mills [6] and Genic et al. [7] are among those researchers who described optimization analysis based primarily on minimizing energy costs related to pumping of a fluid. Kovarik [8] described a technique to optimize a cross flow heat exchanger. The objective function which was employed included cost factors related to the heat exchanger size and pumping power, as well as the required heat transfer rate. Similarly Rao et al. [9] and Caputo et al. [10] proposed methods to minimize capital and operating costs for shell-and-tube heat exchangers while satisfying the required heat transfer duty. Silaipillayarputhur et al [11] developed a pumping system for a heat transfer fluid. Therein, the details for choosing an appropriate pump, head loss calculations, net positive suction head (NPSH) calculations are detailed and such concepts are applied in this work while designing pumping system for the heat exchanger.

\section{Nomenclature}

Symbol Name

A Heat exchanger surface area $\left(\mathrm{m}^{2}\right)$

ADP Apparatus dew point temperature $\left({ }^{\circ} \mathrm{C}\right)$

BP Bypass factor (dimensionless)

$\mathrm{C}_{\mathrm{min}} \quad$ Minimum capacity rate $(\mathrm{W} / \mathrm{K})$

$\mathrm{C}_{\max } \quad$ Maximum capacity rate $(\mathrm{W} / \mathrm{K})$

COP Coefficient of performance (dimensionless)

$\mathrm{C}_{\mathrm{p}} \quad$ Specific heat (J/kg.K)

$\mathrm{C}_{\mathrm{r}} \quad$ Capacity rate ratio (dimensionless)

$\mathrm{h} \quad$ Enthalpy $(\mathrm{kJ} / \mathrm{kg})$

$\dot{\mathrm{m}} \quad$ Mass flow rate $(\mathrm{kg} / \mathrm{s})$

$\mathrm{n} \quad$ Number of passes (dimensionless)

NTU Number of transfer units (dimensionless)

Q Volume flow rate $\left(\mathrm{m}^{3} / \mathrm{s}\right)$

$\dot{Q} \quad$ Rate of heat transfer (W)

$\dot{\mathrm{W}}_{\mathrm{c}} \quad$ Compressor work (W)

$\mathrm{T} \quad$ Temperature $\left({ }^{\circ} \mathrm{C}\right)$

$\mathrm{U} \quad$ Overall heat transfer coefficient $\left(\mathrm{W} / \mathrm{m}^{2} \mathrm{~K}\right)$

$\Delta \mathrm{T}_{\mathrm{m}} \quad$ Log mean temperature difference $(\mathrm{K})$

Symbols

$\rho \quad$ Density $\left(\mathrm{kg} / \mathrm{m}^{3}\right)$

$\epsilon \quad$ Effectiveness (dimensionless)

$\eta \quad$ Efficiency (dimensionless)

Subscripts

hi Hot fluid inlet

ho Hot fluid exit

ci Cold fluid inlet

co Cold fluid exit

A Minimum capacity rate fluid

B Maximum capacity rate fluid

1 One shell pass, multiple tube passes (shell and tube heat exchanger)

Superscripts

Per pass (cross flow heat exchanger)

\section{Basic layout of the cooling system}

This project considers the design of a cooling system for cooling $8480 \mathrm{CFM}$ of air from $72^{\circ} \mathrm{F}$ to $58^{\circ} \mathrm{F}$. The cooling system is described in Figure 1. As described before, the cooling system consists of a cross flow heat exchanger where the air is cooled by chilled water, a refrigeration system for cooling the chilled water and a cooling water system for cooling the refrigerant in the refrigeration unit.

In this project, a basic design for the cross flow heat exchanger is considered. Therein, performance charts describing the performance of the heat exchanger in terms of significant dimensionless parameters are developed. The parameters are number of transfer units (NTU), capacity rate ratio $\left(\mathrm{C}_{\mathrm{r}}\right)$, and heat exchanger effectiveness $(\varepsilon)$. These three parameters completely describe the heat exchanger as they encompass physical, thermal, fluid, and material characteristics of the heat exchanger. Domingos approach [3] was employed in the development of performance charts. Using these charts engineers can quickly determine the required NTU and capacity rate ratio for the heat exchanger. Using these parameters, it is fairly straight forward to extrapolate the detailed design of the heat exchanger. The development of performance charts is described in the subsequent sections of this paper. Likewise, the development of a basic refrigeration cycle is also considered in the paper. The choice of refrigerant, capacities for evaporator \& condenser equipment, and requirements for the compressor were all computed. Therein, it must be recognized that the evaporator and condenser equipment are basically shell and tube heat exchangers and performance charts for shell and tube heat exchangers were developed by using the explicit relations provided in [12]. Thereafter, the basic design for the evaporator and condenser equipment were developed as well.

The cooling system must be sized such that the required cooling is provided in the quench cabinets. The mass flow rate of air can be determined as follows.

$$
\dot{\mathrm{m}}_{\text {air }}=\rho \mathrm{Q}
$$

Where $\rho$ is the density of air and Q is the flow rate of air. Therefore, the required amount of cooling in the cross flow heat exchanger can be readily computed as follows

$\dot{\mathrm{Q}}_{\mathrm{air}}=\dot{\mathrm{m}}_{\text {air }} \mathrm{c}_{\mathrm{p}, \text { air }}\left[\mathrm{T}_{\mathrm{Ai}}-\mathrm{T}_{\mathrm{Ao}}\right]$

Here $c_{p, a i r}$ is the specific heat of air and $\mathrm{T}_{\mathrm{Ai}}$ and $\mathrm{T}_{\mathrm{AO}}$ are inlet and discharge temperatures of air respectively. From Equation (2), the required cooling load for the system can be readily determined.

Performance charts for cross flow heat exchanger

Consider a cross flow heat exchanger as described in Figures 2 and 3. Therein, the external fluid is in gaseous form and tube side fluid is in liquid state. The overall NTU of the heat exchanger can be described as follows [12]

$$
\mathrm{NTU}=\frac{\mathrm{UA}}{\mathrm{C}_{\min }}
$$

Most heat exchangers in process industries are configured such that the external fluid, the gas, is the minimum capacity rate fluid and therefore the NTU of the heat exchanger may be given as

$$
\mathrm{NTU}=\frac{\mathrm{UA}}{\mathrm{m}_{\mathrm{A}} \mathrm{Cp}_{\mathrm{A}}}
$$

Herein, subscript A refers to the minimum capacity rate fluid. Likewise, the capacity rate ratio of the heat exchanger may be given as 


$$
\mathrm{C}_{\mathrm{r}}=\frac{\mathrm{C}_{\min }}{\mathrm{C}_{\max }}
$$

Assuming that external fluid is the minimum capacity rate fluid

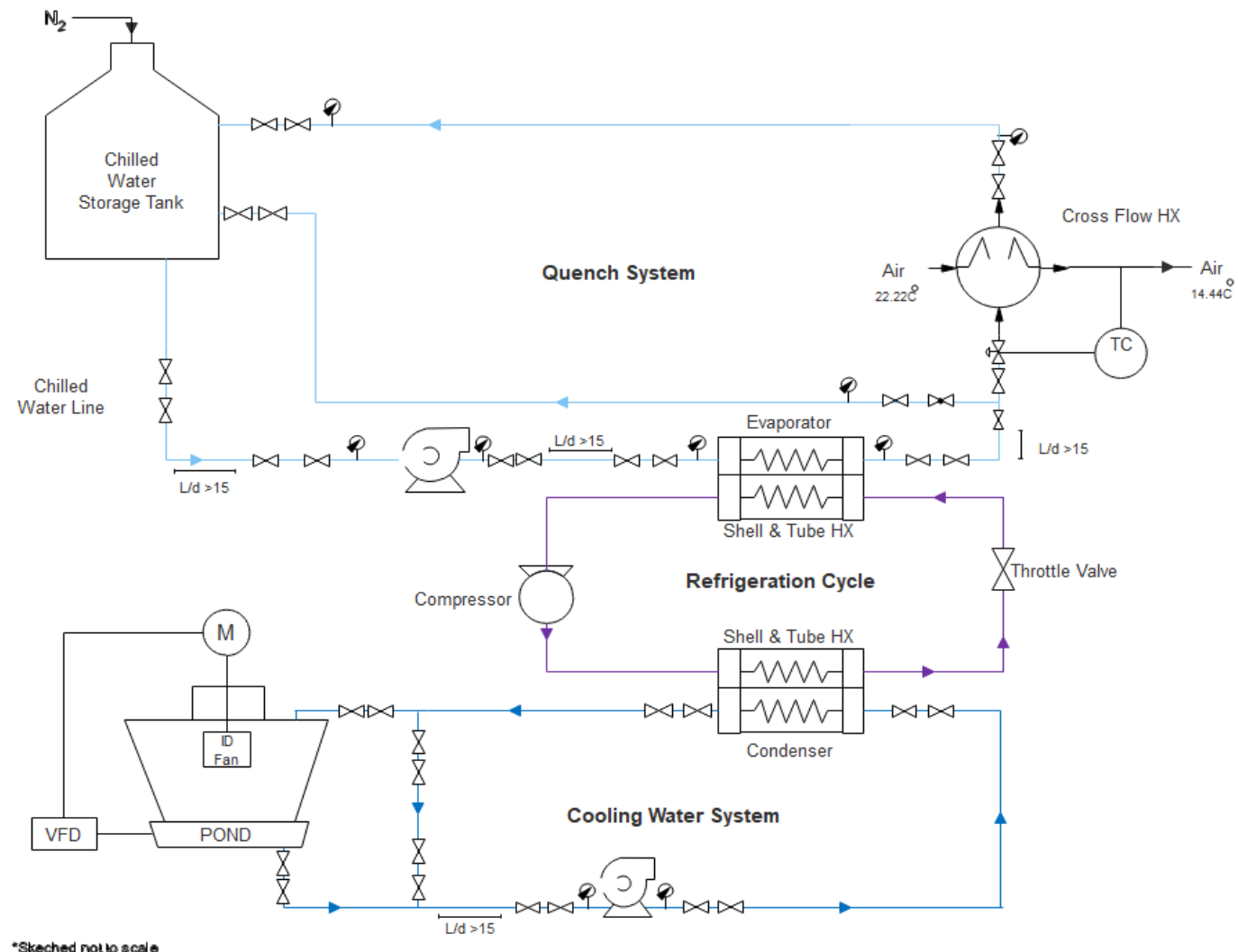

Fig. 1: Basic Layout of the Cooling System.

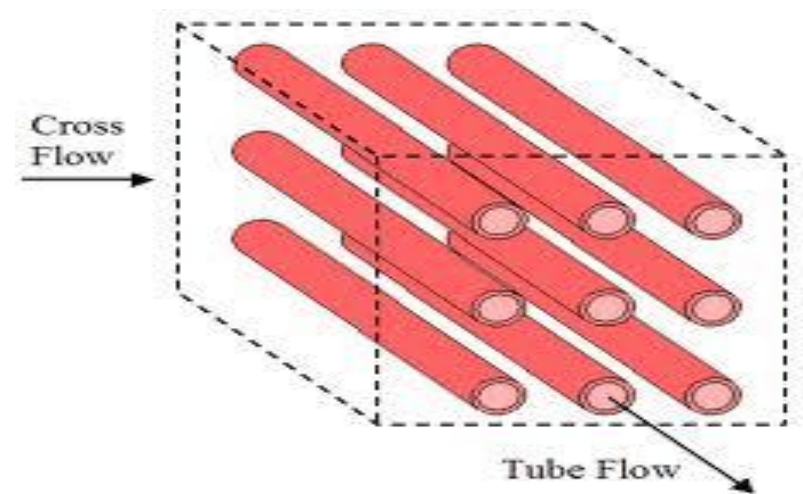

Fig. 2: Cross Flow Heat Exchanger.

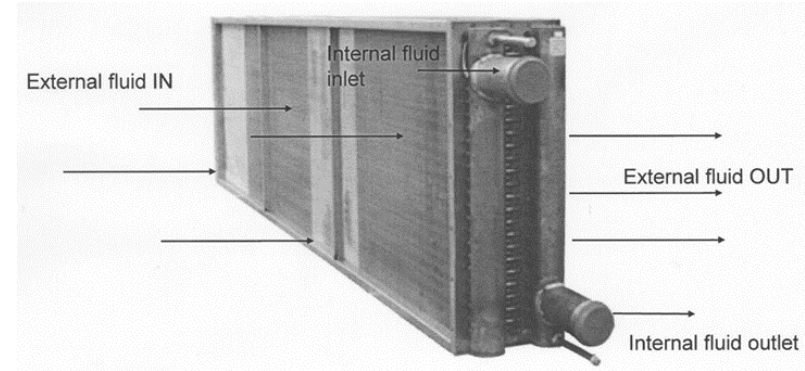

Fig. 3: Finned Cross Flow Heat Exchanger (Parallel Flow Configuration).

A cross flow heat exchanger can have several passes. A heat exchanger "pass" may be visualized as the number of times a tube side fluid particle travels through the entire length of the heat exchanger.

$$
\mathrm{C}_{\mathrm{r}}=\frac{\mathrm{m}_{\mathrm{A}} \mathrm{Cp} \mathrm{p}_{\mathrm{A}}}{\mathrm{m}_{\mathrm{B}} \mathrm{Cp} \mathrm{p}_{\mathrm{B}}}
$$

Where subscript B refers to the maximum capacity rate fluid. 
mass flow rate of the external fluid. Therefore, capacity rate ratio per pass may then be given as

$$
\mathrm{C}_{\mathrm{r}}^{\prime}=\mathrm{C}_{\mathrm{r}}
$$

The effectiveness per pass of a cross flow heat exchanger may be given as [12]

$$
\varepsilon^{\prime}=1-\exp \left[\left(\frac{1}{\mathrm{C}_{\mathrm{r}}^{\prime}}\right) * \mathrm{NTU}^{\prime 0.22} *\left(\exp \left[-\mathrm{C}_{\mathrm{r}}^{\prime} * \mathrm{NTU}^{\prime 0.78}\right]\right)-1\right]
$$

From Domingos [3], for a parallel flow heat exchanger, the overall effectiveness of the heat exchanger may be given as
And from Domingos [3], for a counter flow heat exchanger, the overall effectiveness of the heat exchanger may be given as

$$
\varepsilon=\frac{n \varepsilon^{\prime}}{1+(\mathrm{n}-1) \varepsilon^{\prime}}
$$

Performance charts for the parallel cross flow heat exchanger were developed by employing Equations (9) and (10) and whereas performance charts for counter cross flow heat exchanger were developed by employing Equations (9) and (11). The NTU of the heat exchanger was arbitrarily varied between 0.1 and 10 , as this is the common working range of NTU seen in process industries. The capacity rate ratio is varied between the limits of 0 and 1 .

$\varepsilon=\frac{1-\left[1-\varepsilon^{\prime}\left(\mathrm{C}_{\mathrm{r}}^{\prime}+1\right)\right]^{\mathrm{n}}}{\mathrm{C}_{\mathrm{r}}^{\prime}+1}$

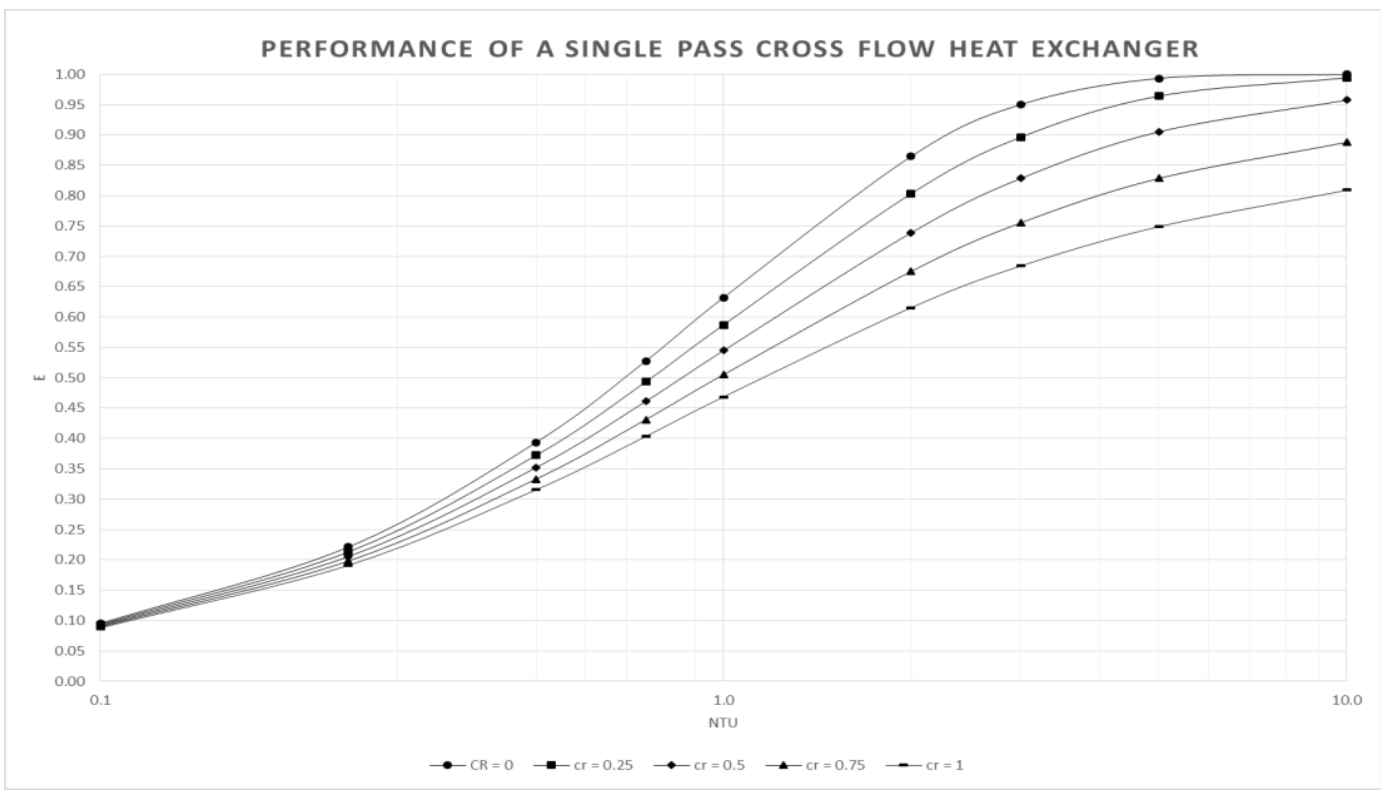

Fig. 6: Performance Chart - Single Pass Cross Flow Heat Exchanger.

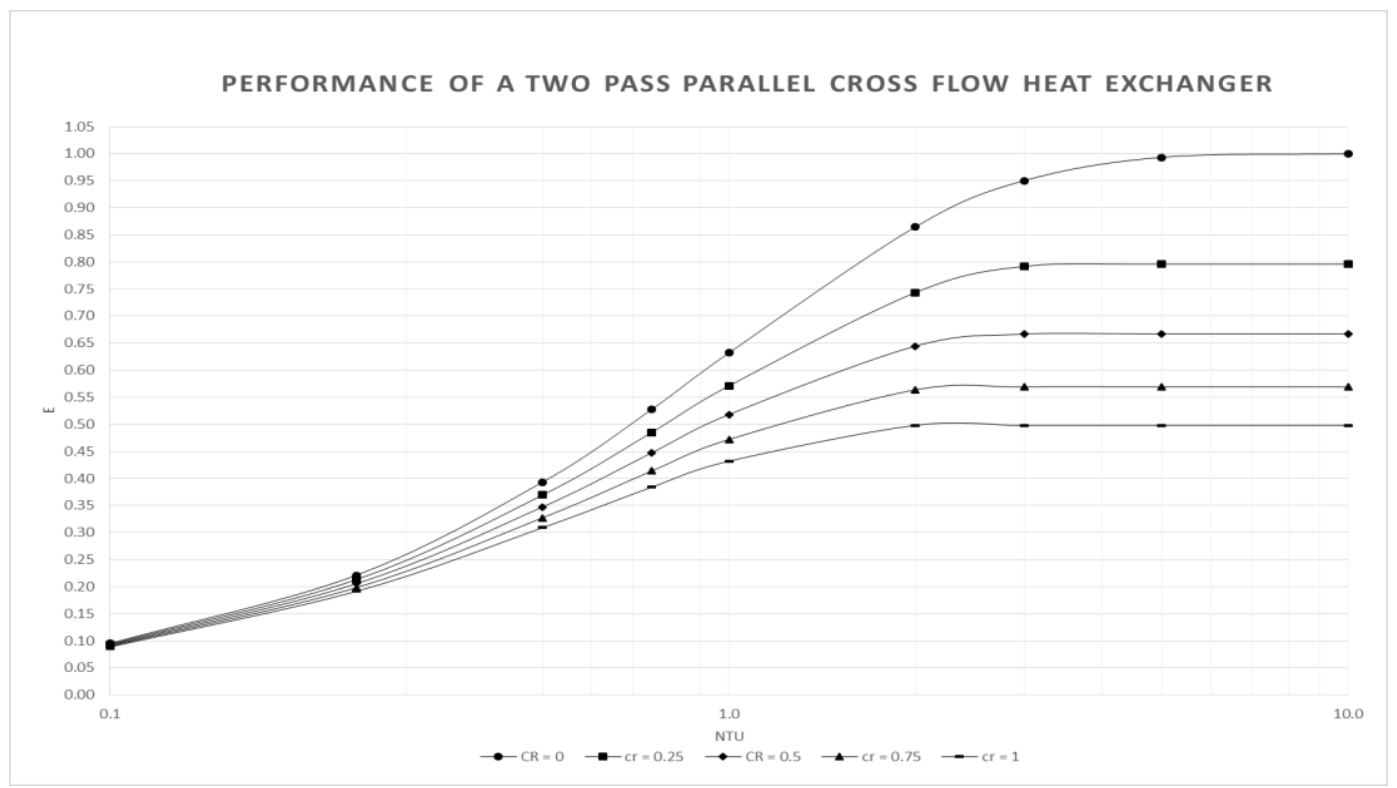

Fig. 7: Performance Chart - Two Pass Parallel Cross Flow Heat Exchanger. 


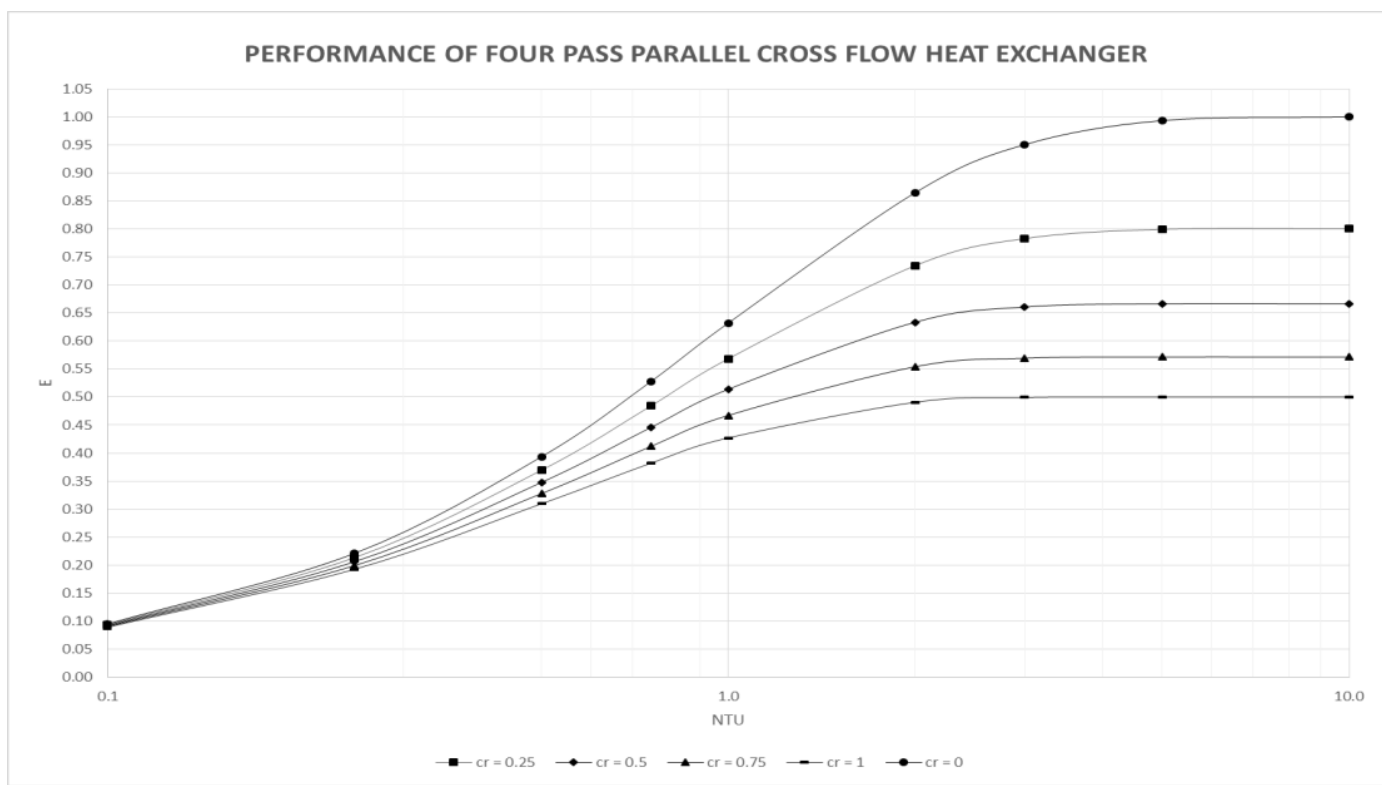

Fig. 8: Performance Chart - Four Pass Parallel Cross Flow Heat Exchanger.

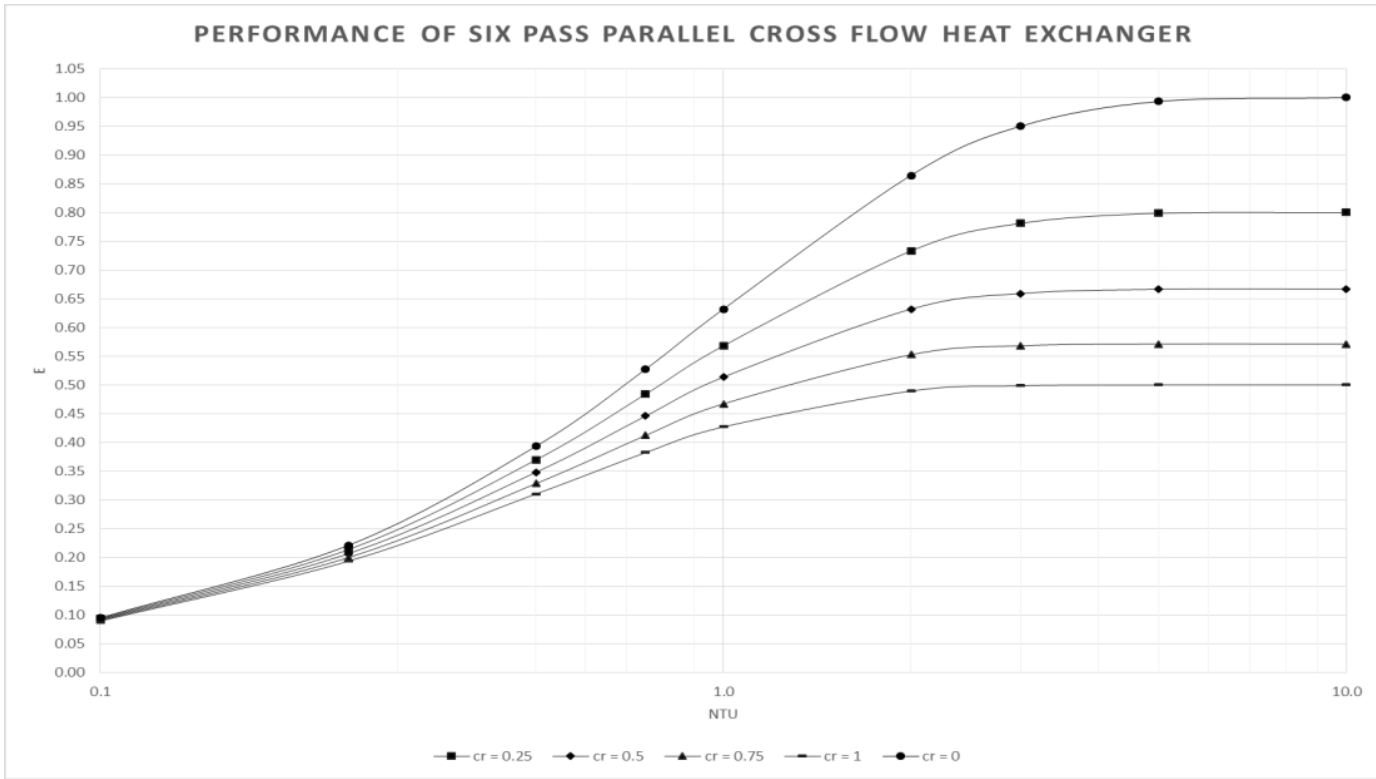

Fig. 9: Performance Chart - Six Pass Parallel Cross Flow Heat Exchanger.

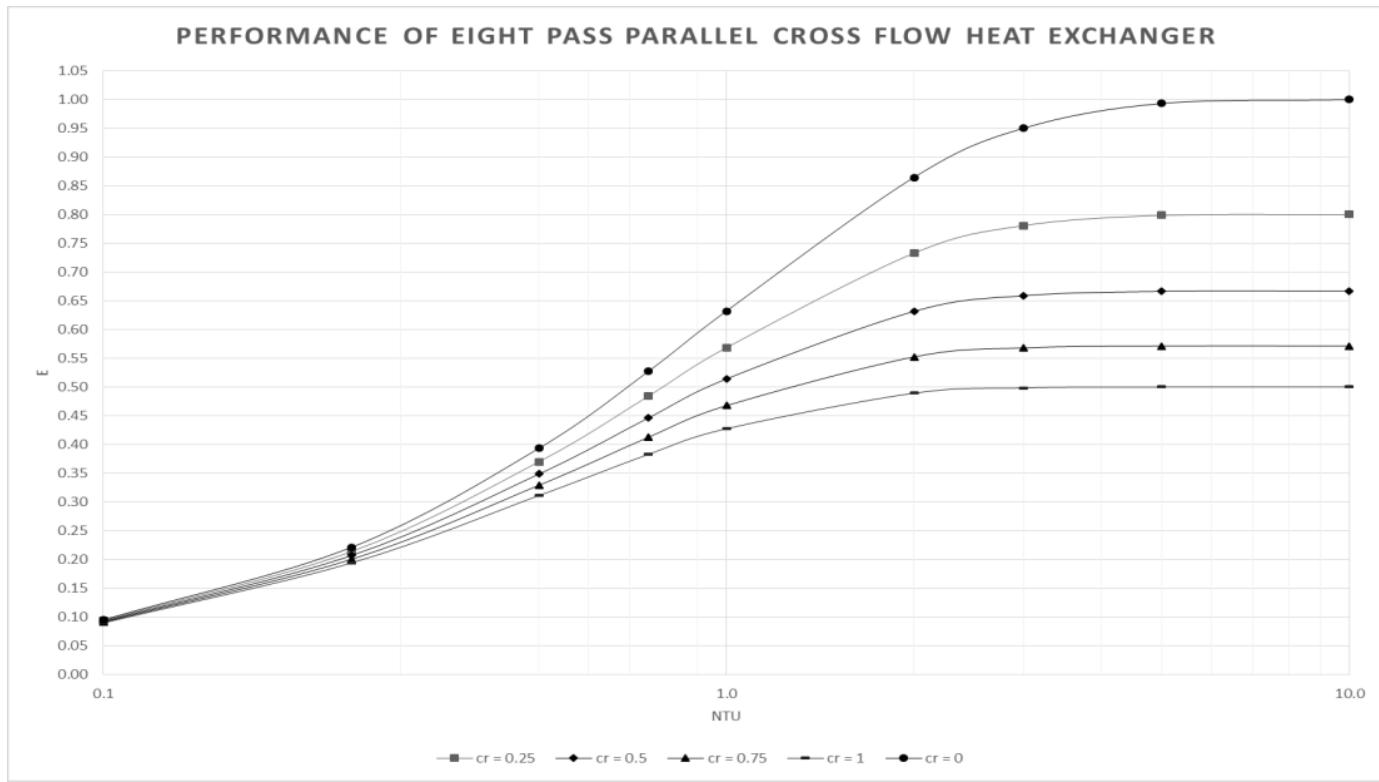

Fig. 10: Performance Chart - Eight Pass Parallel Cross Flow Heat Exchanger. 
PERFORMANCE OF TEN PASS PARALLEL CROSS FLOW HEAT EXCHANGER

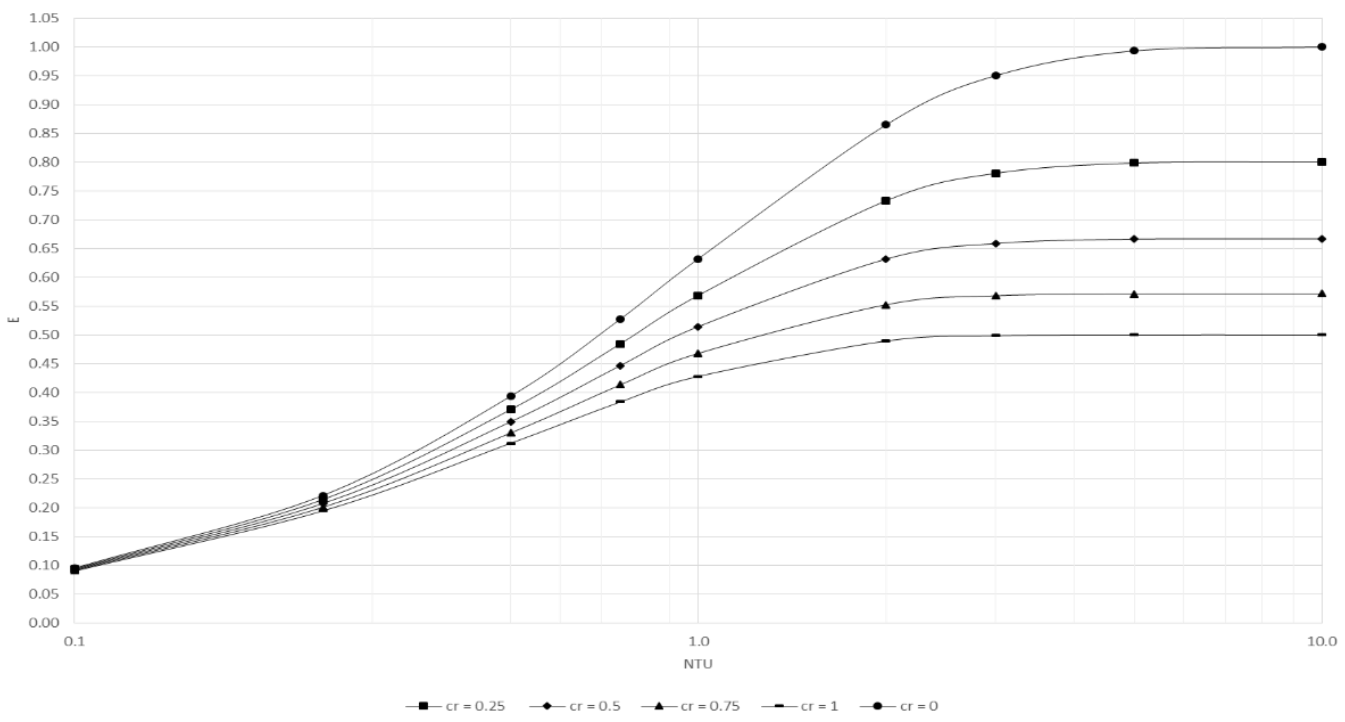

Fig. 11: Performance Chart - Ten Pass Parallel Cross Flow Heat Exchanger.

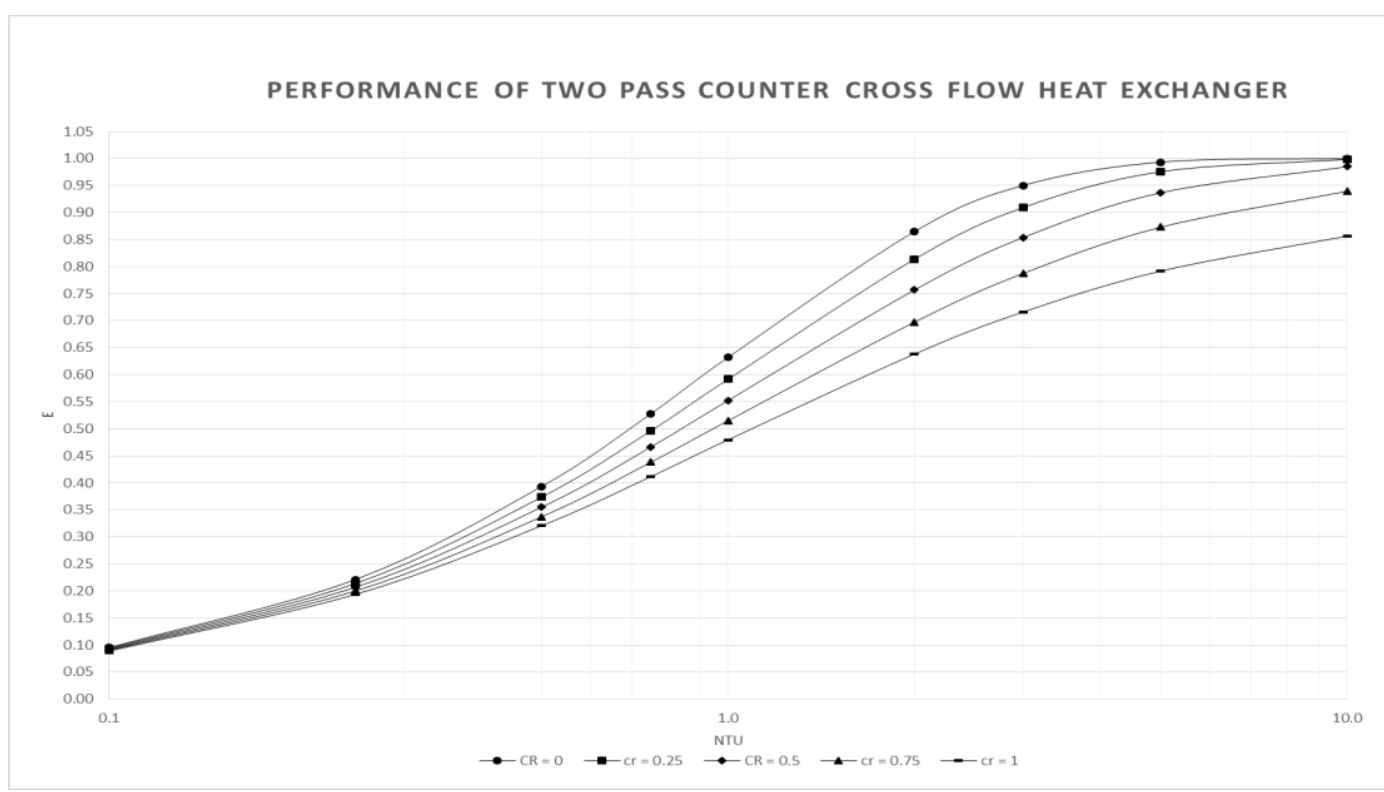

Fig. 12: Performance Chart - Two Pass Counter Cross Flow Heat Exchanger.

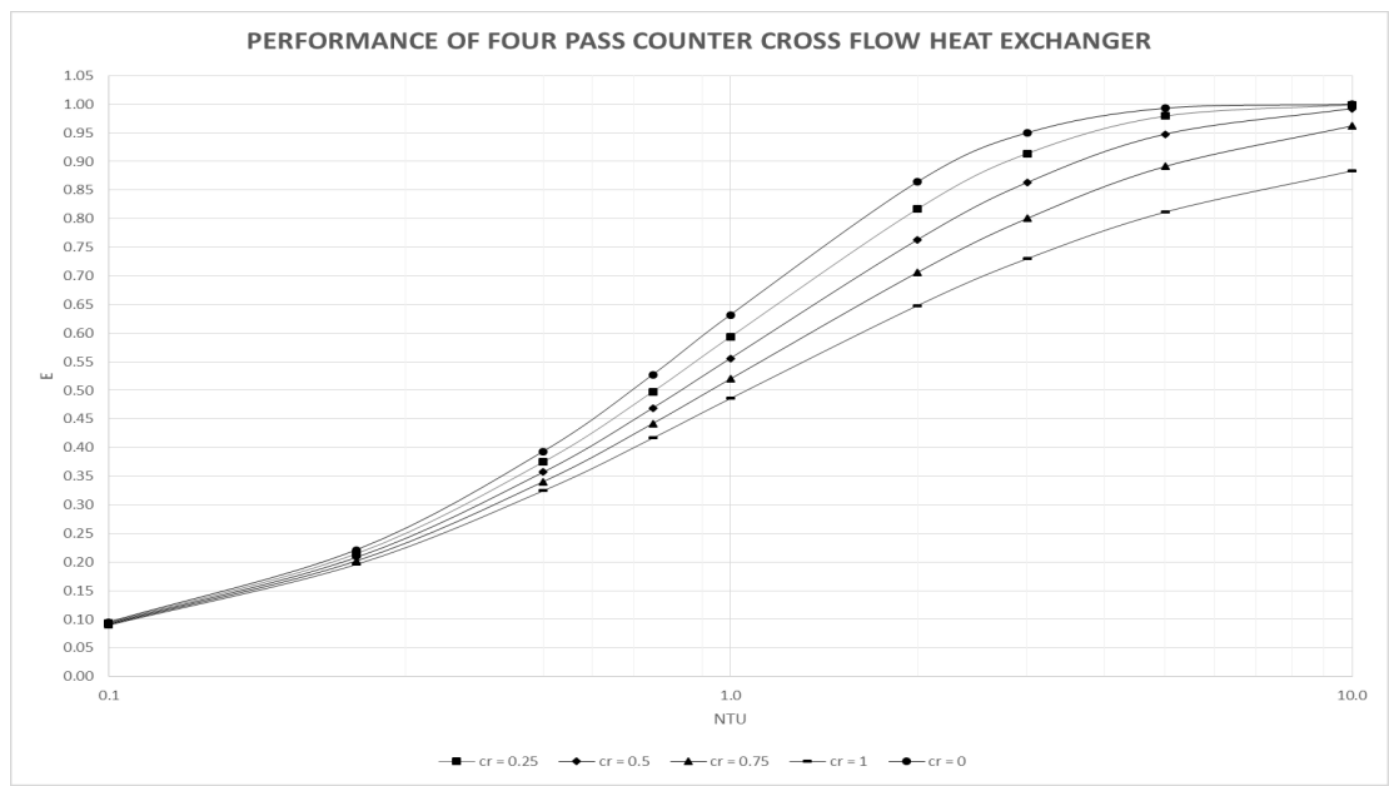

Fig. 13: Performance Chart - Four Pass Counter Cross Flow Heat Exchanger. 


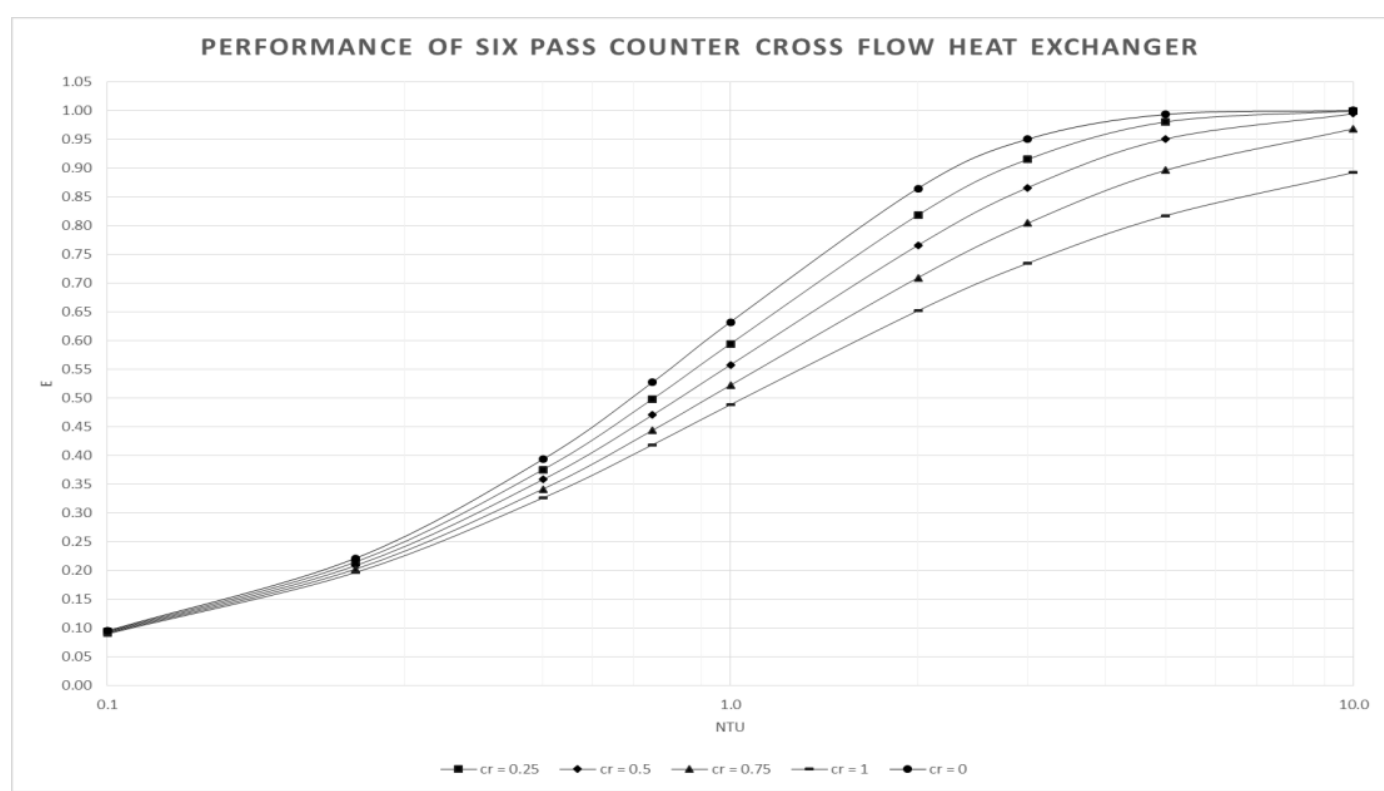

Fig. 14: Performance Chart - Six Pass Counter Cross Flow Heat Exchanger.

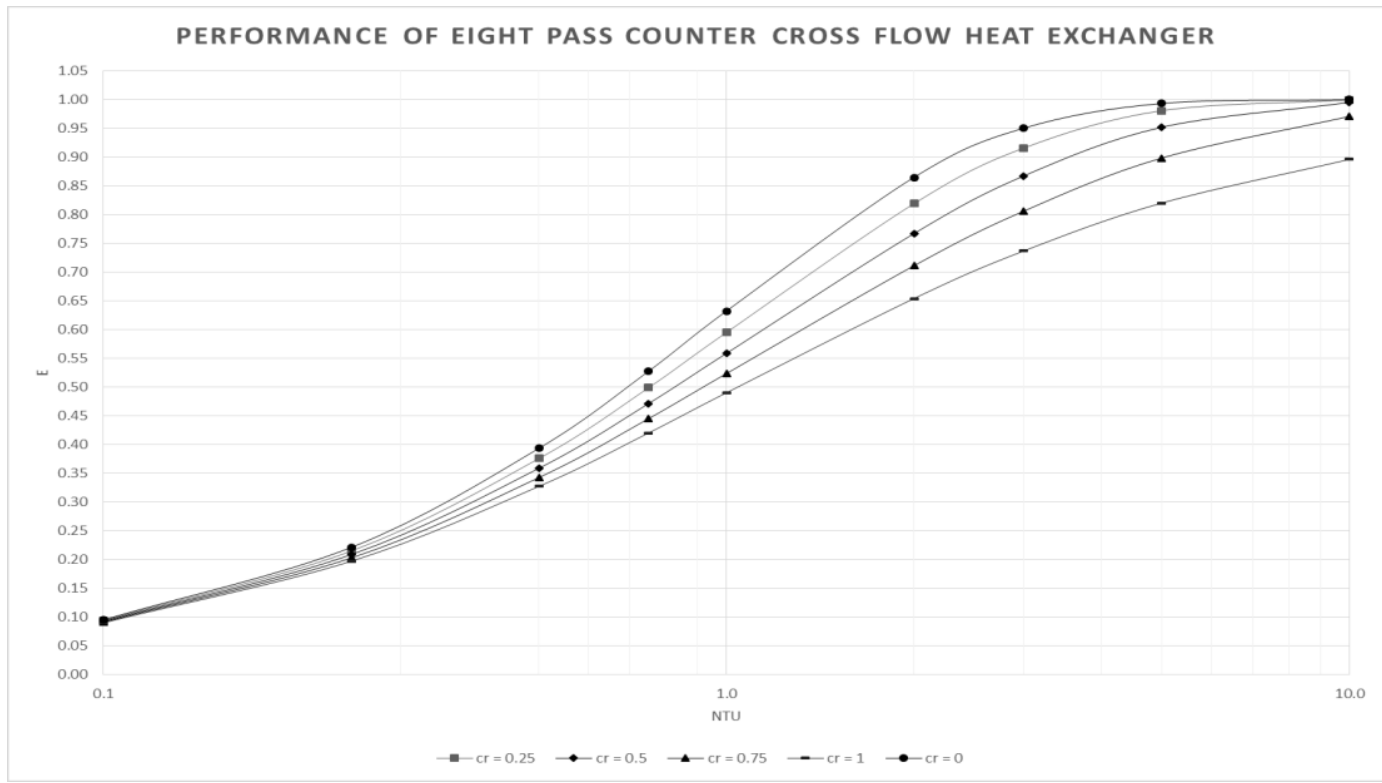

Fig. 15: Performance Chart - Eight Pass Counter Cross Flow Heat Exchanger.

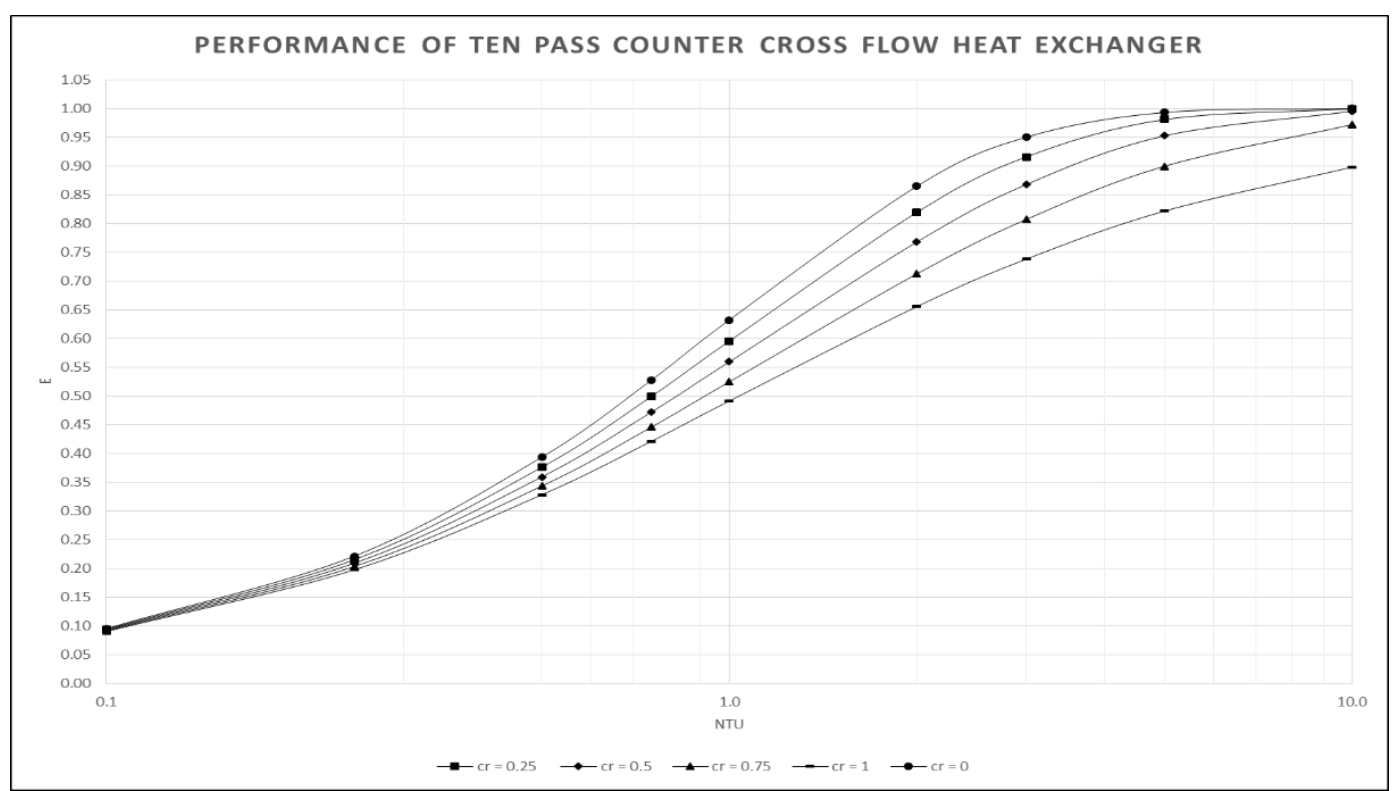

Fig. 16: Performance Chart - Ten Pass Counter Cross Flow Heat Exchanger. 
Using the performance charts, the basic design of the cross flow heat exchanger can be ascertained. The basic design involves determination of the required NTU and capacity rate ratio for the cross flow heat exchanger. Heat exchangers are often characterized by NTU as they account for all the properties of the heat exchanger, size and configuration. These are described in the subsequent sections. From the basic design, it is easy to develop a detailed design for the cross flow heat exchanger. The basic design of the cross flow heat exchanger is described in Figures 17 and 18.

Inputs for the design of cross flow heat exchanger
\begin{tabular}{|l|c|c|c|c|}
\hline Air volume flow rate & 8480 & $\mathrm{ft}^{3} / \mathrm{min}$ & 4 & $\mathrm{~m}^{3} / \mathrm{s}$ \\
\hline Air density & 1.2 & $\mathrm{~kg} / \mathrm{m}^{3}$ & & \\
\hline Air supply tempreture & 72 & ${ }^{\circ} \mathrm{F}$ & 22.4 & ${ }^{\circ} \mathrm{C}$ \\
\hline Required air discharge tempreture & 56 & ${ }^{\circ} \mathrm{F}$ & 14.6 & ${ }^{\circ} \mathrm{C}$ \\
\hline Chilled water inlet temperature (assumed) & 10 & ${ }^{\circ} \mathrm{C}$ & 22.4 & ${ }^{\circ} \mathrm{C}$ \\
\hline Specific heat of air $c_{\text {p,air }}$ & 1.005 & $\mathrm{~kJ} / \mathrm{kg} \cdot \mathrm{k}$ & 1005 & $\mathrm{~J} / \mathrm{kg} \cdot \mathrm{K}$ \\
\hline Specific heat of chilled water $c_{\mathrm{p}, \text { water }}$ & 4.192 & $\mathrm{~kJ} / \mathrm{kg} \cdot \mathrm{k}$ & 4192 & $\mathrm{~J} / \mathrm{kg} \cdot \mathrm{K}$ \\
\hline Minimum capacity rate fluid - cross flow heat exchanger & Air & & & \\
\hline Maximum capacity rate fluid - cross flow heat exchanger & Chilled water & & & \\
\hline
\end{tabular}

Fig. 17: Inputs for the Design of Cross Flow Heat Exchanger.

Cross flow heat exchanger design calculations
\begin{tabular}{|l|c|c|c|c|c|c|}
\hline Air mass flow rate & 4.8 & $\mathrm{~kg} / \mathrm{s}$ & & & & \\
\hline Cross flow heat exchanger load & 37.6 & $\mathrm{kw}$ & 135458 & $\mathrm{~kJ} / \mathrm{hr}$ & 11 & ton \\
\hline Required heat exchanger effectiveness & 0.63 & & & & & \\
\hline Selected HX configuration & counter & & & & & \\
\hline Required NTU (chosen from performance charts) & 1.2 & & & & & \\
\hline Required \# of passes (chosen from performance charts) & 4 & & & & & \\
\hline Required capacity rate ratio (chosen from performance charts) & 0.25 & & & & & \\
\hline Capacity rate of air & 4824 & $\mathrm{~W} / \mathrm{K}$ & & & & \\
\hline Required capacity rate of chilled water & 19296 & $\mathrm{~W} / \mathrm{K}$ & & & & \\
\hline Required mass flow rate of chilled water & 4.6 & $\mathrm{~kg} / \mathrm{s}$ & & & & \\
\hline Anticipated chilled water discharge temperature & 12.0 & ${ }^{\circ} \mathrm{C}$ & & & & \\
\hline
\end{tabular}

Fig. 18: Cross Flow Heat Exchanger Basic Design Calculations.

\section{Design of the refrigeration cycle}

Design of the refrigeration cycle consists of the selection of the refrigerant, calculating mass flow rate of the refrigerant, determining the operating conditions for evaporator and condenser, and selection of a compressor and a throttling device. There are several refrigerants that can be employed for the refrigeration system. However, the most popular and the environmentally friendly refrigerant is R134a (Tetrafluoroethane) is chosen for this application. Consider Figure 19. describing the various components of the vapor compression refrigeration cycle.

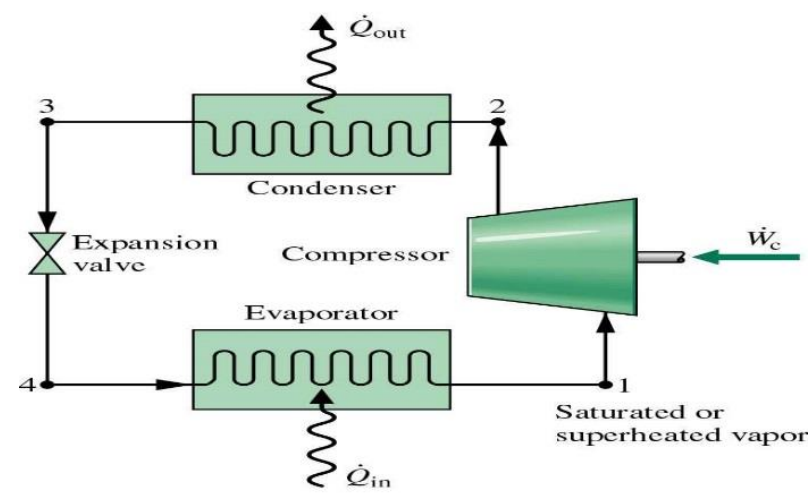

Fig. 19: Vapor Compression Refrigeration System.
The following are the assumptions employed in the development of the refrigeration cycle:

1) Evaporator and condenser operate at constant pressure.

2) Compressor efficiencies vary with compressor type, size, and throughput. They can only be determined by a compressor test, although compressor manufacturers can usually provide good estimates. For planning purposes, the compressor efficiency may be assumed as 0.85 ; (i.e.) $\eta_{c}=0.85$ [13].

3) The by pass (BP) factor, the parameter that describes the percentage of air that is not cooled to the apparatus dew point temperature (the surface temperature of the evaporator coil) can be assumed as 0.2 ; (i.e.) $\mathrm{BP}=0.2$.

4) The refrigerant is a saturated vapor entering the compressor.

5) The refrigeration unit (the chiller) is assumed to be a water cooled chiller as described in Figure 1.

6) The condenser operating temperature and pressure is dependent on the condensing temperature of the refrigerant in the condenser.

The condensing temperature of the refrigerant is fixed based on the available cooling water temperature and the worst environmental conditions.

7) The refrigerant is a saturated liquid leaving the condenser. Considering Figure 1, it can be clearly seen that the evaporator is a shell and tube heat exchanger wherein the refrigerant exchanges heat with the chilled water. As always, the refrigerant does not mix with chilled water and they are separated by means of a solid wall. Recall that the rate of cooling in the cross flow heat exchanger is known from Equation (2). Recognize that the cross flow heat exchanger effectiveness or the efficiency of the heat exchanger may 
also be described as the ratio of heat transfer to the maximum possible heat transfer, thus

$$
\begin{aligned}
& \varepsilon=\frac{\dot{\mathrm{Q}}}{\dot{\mathrm{Q}}_{\max }} \\
& \text { Or } \\
& \varepsilon=\frac{\dot{\mathrm{Q}}}{\mathrm{C}_{\min }\left[\mathrm{T}_{\mathrm{Ai}}-\mathrm{T}_{\mathrm{Bi}}\right]}
\end{aligned}
$$

By assuming a suitable inlet temperature for the chilled water, the required effectiveness of the cross flow heat exchanger can be readily computed. Thereafter, employing performance charts, a reasonable capacity rate ratio and the NTU for the heat exchanger can be determined.

The capacity rate ratio is described by Equation (6). By employing Equation (6), the required mass flow rate of chilled water can be readily computed. Applying energy balance to the chilled water yields

$$
\mathrm{Q}_{\text {water,chilled }}=\dot{\mathrm{m}}_{\text {water,chilled }} \mathrm{c}_{\mathrm{p} \text {,water }}\left[\mathrm{T}_{\mathrm{BO}}-\mathrm{T}_{\mathrm{Bi}}\right]
$$

Here, $T_{\mathrm{Bi}}$ refers to the chilled water supply temperature in the cross flow heat exchanger and $\mathrm{T}_{\mathrm{BO}}$ refers to the chilled water discharge temperature from the cross flow heat exchanger.

The rate of heat transfer to the cooling water or the heat gained by the cooling water is equal to the rate of heat loss from air.

$$
\mathrm{Q}_{\text {water,chilled }}=\mathrm{Q}_{\text {air }}
$$

Employing Equations (14) and (15), the chilled water discharge temperature from the cross flow heat exchanger can be readily computed.

The by pass factor of the evaporator coil may be defined as

$$
\mathrm{BP}=\frac{\mathrm{T}_{\mathrm{c}, \text { in }}-\mathrm{ADP}}{\mathrm{T}_{\mathrm{c}, \text { out }}-\mathrm{ADP}}
$$

Where $T_{c, \text { in }}$ refers to the temperature of chilled water entering the evaporator and $\mathrm{T}_{\mathrm{c}, \text { out }}$ refers to the temperature of chilled water leaving the evaporator. It must be recognized that the chilled water leaving the evaporator feeds the cross flow heat exchanger (chilled water supply) and the chilled water leaving the cross flow heat exchanger (chilled water return) enters the evaporator. Therefore Equation (16) may be rewritten as
$\mathrm{BP}=\frac{\mathrm{T}_{\mathrm{BO}}-\mathrm{ADP}}{\mathrm{T}_{\mathrm{Bi}}-\mathrm{ADP}}$

Except ADP, all parameters in Equation (17) are known. This will help to determine the ADP and the working temperature and pressure of the refrigerant in the evaporator coil.

The condenser operating temperature and pressure is set based on condensing temperature of the refrigerant. The compressor work can be described as follows:

$$
\dot{\mathrm{W}}_{\mathrm{c}}=\dot{\mathrm{m}}_{\mathrm{ref}}\left[\mathrm{h}_{1}-\mathrm{h}_{2}\right]
$$

The condenser, a shell and tube heat exchanger as well, is designed such that the refrigerant leaves the condenser as a saturated liquid. The condenser working pressure and temperature is chosen such that the cooling water provided by the cooling tower can condense the refrigerant to a saturated liquid. Likewise, the expansion in a thermostatic expansion valve can be assumed as an isoenthalpic process, such that

$$
\mathrm{h}_{3}=\mathrm{h}_{4}
$$

The required mass flow rate of the refrigerant can then be determined by applying energy balance to the evaporator

$$
\dot{\mathrm{Q}}_{\text {evaporator }}=\dot{\mathrm{m}}_{\text {ref }}\left[\mathrm{h}_{1}-\mathrm{h}_{4}\right]
$$

Recognize that

$$
\dot{\mathrm{Q}}_{\text {air }}=\dot{\mathrm{Q}}_{\text {water, chilled }}=\dot{\mathrm{Q}}_{\text {evaporator }}
$$

The above Equation describes that the rate of heat transfer from the air is equal to the rate of heat absorbed by the chilled water which is likewise equal to the rate of heat absorbed by the refrigerant in the evaporator. The coefficient of the refrigeration (COP) cycle is described as

$\mathrm{COP}=\frac{\mathrm{Q}_{\text {evaporator }}}{\dot{\mathrm{W}}_{\mathrm{c}}}$

The development of the refrigeration cycle is in Figures 20 and 21.

Inputs for the design of refrigeration cycle
\begin{tabular}{|l|c|c|c|c|}
\hline Refrigerant & R134a & & & \\
\hline By pass factor (evaporator) & 0.2 & & & \\
\hline Minimum capacity rate fluid - evaporator & Chilled Water & & & \\
\hline Maximum capacity rate fluid - evaporator & Refrigerant (R134a) & & & \\
\hline Compresser effeciency & 0.85 & & & \\
\hline Al hasa worst case ambient temperature (DBT) & 45 & ${ }^{\circ} \mathrm{C}$ & & \\
\hline Al hasa worst case relative humidity (RH) & 70 & $\%$ & & \\
\hline Wet bulb temperature (corresponding to the worst conditions) & 39.39 & ${ }^{\circ} \mathrm{C}$ & & \\
\hline Condenser operating temperature (corresponding to WBT) & 39.39 & ${ }^{\circ} \mathrm{C}$ & & \\
\hline Refrigerant (R134a) phase change (condensing) temperature & 52.43 & ${ }^{\circ} \mathrm{C}$ & & \\
\hline Minimum capacity rate fluid - condenser & Cooling water & & & \\
\hline Maximum capacity rate fluid - condenser & Refrigerant (R134a) & & & \\
\hline Minimum cooling anticipated in cooling tower $(\Delta \mathrm{T})$ & 4 & ${ }^{\circ} \mathrm{C}$ & & \\
\hline
\end{tabular}

Fig. 20: Inputs for the Design of the Refrigeration Cycle. 


\begin{tabular}{|c|c|c|c|c|c|c|}
\hline \multicolumn{7}{|l|}{ Evaporator - shell and tube heat exchanger } \\
\hline Evaporator coil surface temperature (ADP) & 9.513 & ${ }^{\circ} \mathrm{C}$ & & & & \\
\hline Evaporator operating temperature & 8.93 & ${ }^{\circ} \mathrm{C}$ & & & & \\
\hline Evaporator operating pressure (corresponsing to temp) & 4 & bar & & & & \\
\hline Refrigerat (R134a) phase change temperature & 8.93 & ${ }^{\circ} \mathrm{C}$ & & & & \\
\hline Capacity rate ratio of evaportaor & 0 & & & & & \\
\hline Required heat exchanger effectiveness; evaporator & 0.65 & & & & & \\
\hline Required NTU (chosen from performance charts) & 1.75 & & & & & \\
\hline \multicolumn{7}{|l|}{ Condenser - shell and tube heat exchanger } \\
\hline Al Ahsa worst ambient wet bulb temperature & 39.39 & ${ }^{\circ} \mathrm{C}$ & & & & \\
\hline \multirow{2}{*}{$\begin{array}{l}\text { Lowest possible cooling water temperature provided by cooling tower } \\
\text { under worst conditions }\end{array}$} & \multirow{2}{*}{39.39} & \multirow{2}{*}{${ }^{\circ} \mathrm{C}$} & & & & \\
\hline & & & & & & \\
\hline Refrigerant (R134a) condensing temperature & 52.43 & ${ }^{\circ} \mathrm{C}$ & & & & \\
\hline Condenser operating temperature & 52.43 & ${ }^{\circ} \mathrm{C}$ & & & & \\
\hline Condenser operating pressure (corresponding to temp) & 14 & bar & & & & \\
\hline Capacity rate ratio of condenser & 0 & & & & & \\
\hline Required heat exchanger effectiveness; condenser & 0.31 & & & & & \\
\hline Required NTU (chosen from performance charts) & 0.5 & & & & & \\
\hline \multicolumn{7}{|l|}{ Refrigerant properties and cycle calculations } \\
\hline Enthalpy of refrigerant leaving the evaporator (sat. vapor) $\mathrm{h}_{1}$ & 252.32 & $\mathrm{~kJ} / \mathrm{kg}$ & & & & \\
\hline Entropy of refrigerant leaving the evaporator (sat. vapor) $\mathrm{s}_{1}$ & 0.915 & $\mathrm{~kJ} / \mathrm{kg} . \mathrm{K}$ & & & & \\
\hline Entropy of refrigerant leaving compressor (assuming isentropic) $\mathrm{s}_{2 \mathrm{~s}}$ & 0.915 & $\mathrm{~kJ} / \mathrm{kg} . \mathrm{K}$ & & & & \\
\hline Enthaly of refrigerant leaving the compressor (assuming isentropic) $h_{2 s}$ & 278.09 & $\mathrm{~kJ} / \mathrm{kg}$ & & & & \\
\hline Enthalpy of refrigerant leaving the compressor (actual) $h_{2}$ & 282.63 & $\mathrm{~kJ} / \mathrm{kg}$ & & & & \\
\hline Enthalpy of refrigerant leaving the condenser (sat. liquid) $h_{3}$ & 125.26 & $\mathrm{~kJ} / \mathrm{kg}$ & & & & \\
\hline Enthalpy of refrigerant leaving the expansion valve $\mathrm{h}_{4}$ & 125.26 & $\mathrm{~kJ} / \mathrm{kg}$ & & & & \\
\hline Evaporator Load & 37.6 & kw & 135458 & $\mathrm{~kJ} / \mathrm{hr}$ & 11 & ton \\
\hline Required referegrint mass flow rate of refrigerant (R134a) & 0.30 & $\mathrm{~kg} / \mathrm{s}$ & 1066 & $\mathrm{~kg} / \mathrm{hr}$ & & \\
\hline Required compressor power & 8.98 & $\mathrm{~kW}$ & 12.03 & hp & & \\
\hline Condenser load & 46.60 & $\mathrm{~kW}$ & 167773 & $\mathrm{~kJ} / \mathrm{hr}$ & 13 & ton \\
\hline Cooling tower load & 46.60 & $\mathrm{~kW}$ & 167773 & $\mathrm{~kJ} / \mathrm{hr}$ & 13 & ton \\
\hline Required mass flow rate of cooling water & 2.78 & $\mathrm{~kg} / \mathrm{s}$ & & & & \\
\hline $\mathrm{COP}$ of the refrigeration system & 4.2 & & & & & \\
\hline
\end{tabular}

Fig. 21: Refrigeration Cycle Basic Design Calculations.

\section{Development of performance charts for shell and tube heat exchanger}

The evaportor and condenser equipment of the refrigeration cycle are shell and tube heat exchangers. These equipment need to be designed to provide the required heat transfer to the refrigerant such that the cycle operates per the requirements. During the basic design of the shell and tube heat exchanger, performance charts describing the variation of shell and tube heat exchanger's effectiveness with respect to NTU and capacity rate ratio are developed. Heat exchanger specifics and steady state performance can be described by three significant parameters. They are NTU, capacity rate ratio and thermal effectiveness. All these parameters are accounted for in the performance charts.

The heat exchanger effectiveness for a shell and tube heat exchanger having one shell pass and multiple tube passes may be given as [12].

$$
\varepsilon_{1}=2\left\{1+\mathrm{C}_{\mathrm{r}}+\left(1+\mathrm{C}_{\mathrm{r}}^{2}\right)^{\frac{1}{2}} * \frac{1+\exp \left[-(\mathrm{NTU})_{1}\left(1+\mathrm{C}_{\mathrm{r}}^{2}\right)^{\frac{1}{2}}\right]}{1-\exp \left[-(\mathrm{NTU})_{1}\left(1+\mathrm{C}_{\mathrm{r}}^{2}\right)^{\frac{1}{2}}\right]}\right\}^{-1}
$$

And:

$\mathrm{NTU}_{1}=\frac{\mathrm{NTU}}{\mathrm{n}}$

Where $\mathrm{n}$ corresponds to the number of shell passes. Likewise, for a heat exchanger having mutiple shell passes and multiple tube passes the overall effectiveness may be given as [12]

$$
\varepsilon=\left[\left(\frac{1-\varepsilon_{1} C_{r}}{1-\varepsilon_{1}}\right)^{n}-1\right]\left[\left(\frac{1-\varepsilon_{1} C_{r}}{1-\varepsilon_{1}}\right)^{n}-C_{r}\right]^{-1}
$$


Number of transfer units (NTU) is a dimensionless parameter that is widely used by process engineers and heat exchanger designers. NTU is a physically significant dimensionless parameter as it accounts for material characteristics, fluid characteristics, flow characteristics, theraml characteristics, heat exchanger size, fouling, etc.

Using Equations (23), (24), and (25), for a range of NTU varying from 0.1 to 10 , the heat exchanger effectiveness was plotted as a function of capacity rate ratio. Capacity rate ratio is varied between 0 and 1 . The NTU range selected for this study is the commonly seen working range in the process industries.
Consider Figures 22 through 24 describing the performance charts for shell and tube heat exchanger. With the available inputs and the desired output, the heat exchanger's required effectiveness can be readily computed. Thereafter, using the charts, a reasonable NTU and capacity rate ratio that would satify the required heat exchanger effectiveness can be selected. Subsequently, these parameters can be extrapolated using log mean temperature difference (LMTD) and/or $\varepsilon$-NTU approach to yeild the detailed design of the heat exchanger.

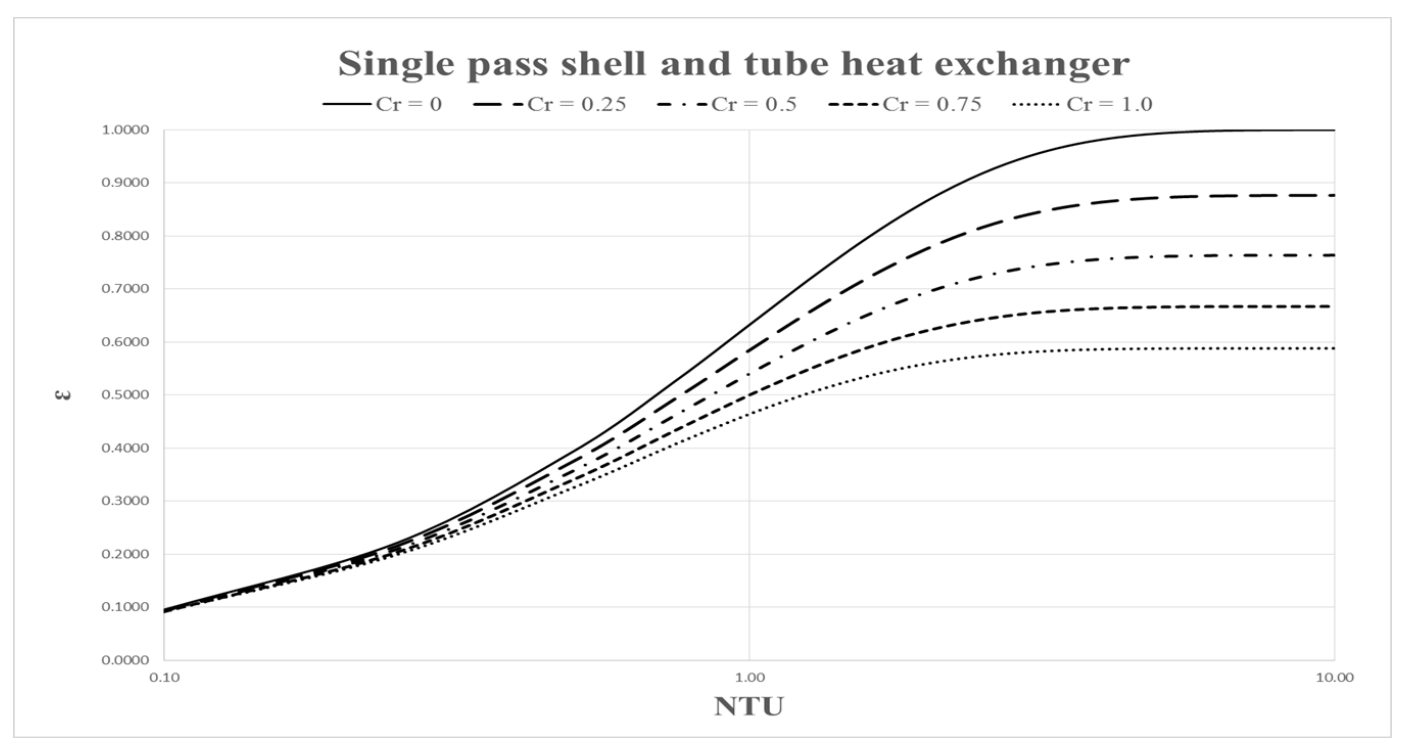

Fig. 22: Performance of A Single Pass Shell and Tube Heat Exchanger.

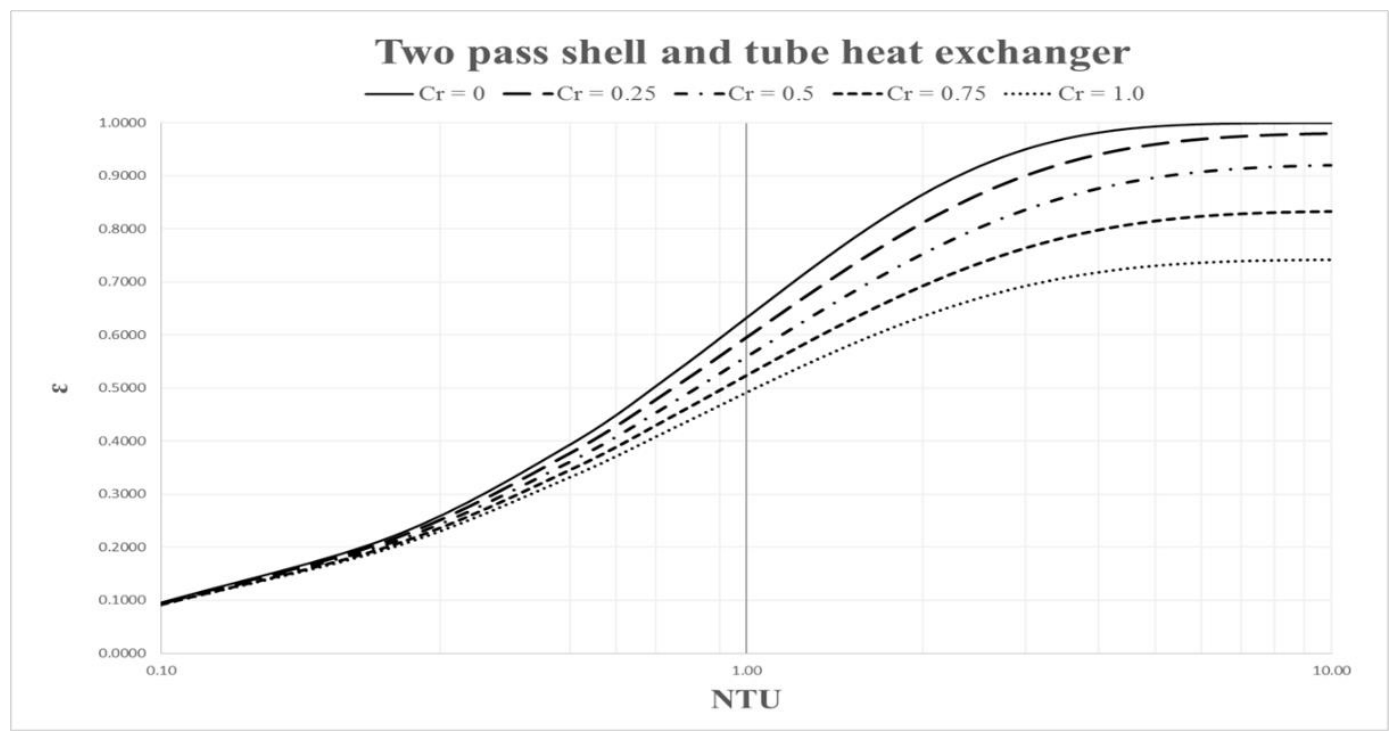

Fig. 23: Performance of A Two Pass Shell and Tube Heat Exchanger. 


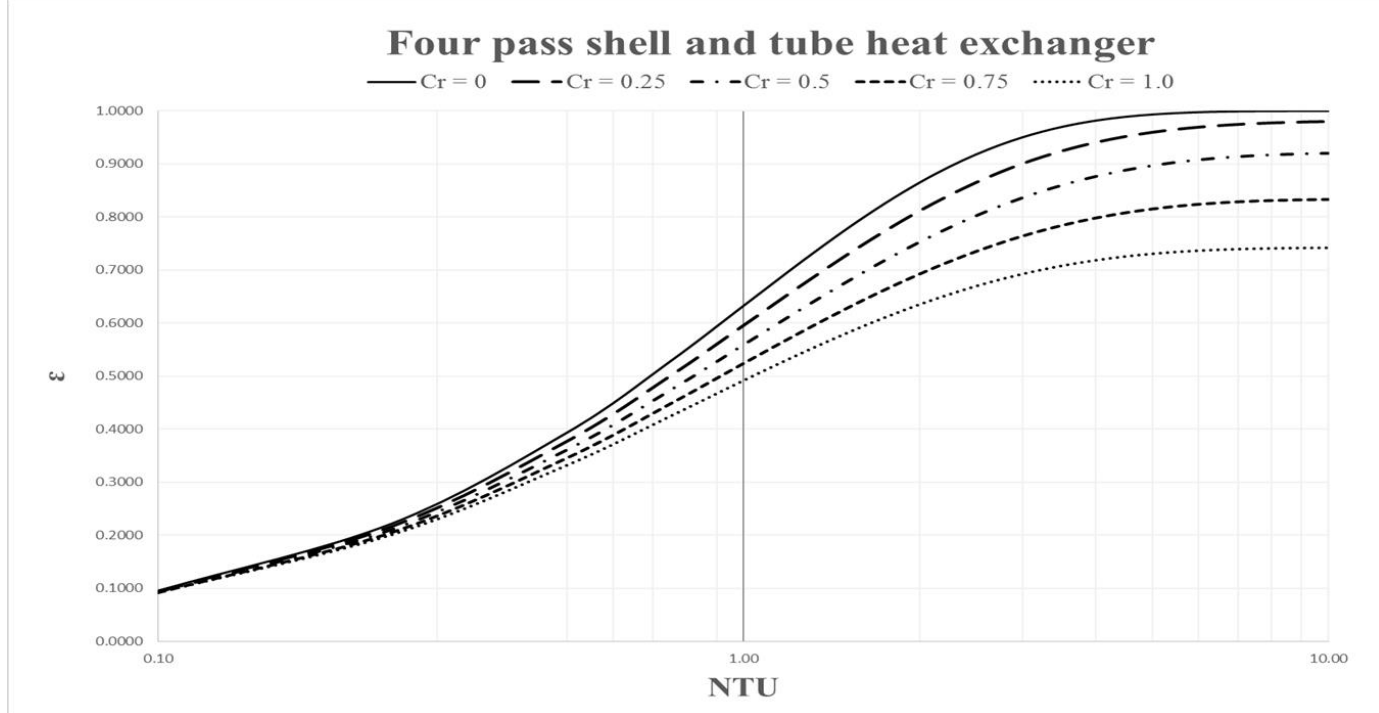

Fig. 24: Performance of A Four Pass Shell and Tube Heat Exchanger.

\section{Design alternatives}

The design alternatives must be considered while designing thermal systems.

\section{Cross flow heat exchanger}

Per the flow configuration, either parallel or counter flow can be considered for the analysis. Performance charts were developed for both parallel and counter cross flow heat exchangers. The difference in the requirements between the parallel and counter cross flow designs are described in Figure 25.

\begin{tabular}{|c|c|}
\hline Parallel Cross Flow & Counter Cross Flow \\
\hline$\varepsilon=0.63$ & $\varepsilon=0.63$ \\
\hline $\mathrm{NTU}=1.5$ & $\mathrm{NTU}=1.2$ \\
\hline $\mathrm{C}_{\mathrm{r}}=0.25$ & $\mathrm{C}_{\mathrm{r}}=0.25$ \\
\hline \# of HX passes $=4$ & \# of HX passes $=4$ \\
\hline
\end{tabular}

Fig. 25: Requirements for Parallel and Counter Cross Flow Heat Exchanger.

From Figure 25, it can be clearly seen that both heat exchangers can deliver the heat transfer requirement. However, the counter cross flow heat exchanger requires a smaller NTU than that of a parallel cross flow heat exchanger. This means that the counter cross flow heat exchanger shall require a smaller surface area for heat transfer, which implies smaller space, less material, less weight and lower cost. Thus, counter cross flow heat exchanger is chosen for the project.

\section{Refrigerant selection}

Various hydrofluorocarbon refrigerants such as R134a, R404A and R41A0A are available in the market. Likewise, hydrochloroflurocarbon refrigerants such as R22 and R408A are also available in the market. Out of all these refrigerants, the most popular, the readily available and the environmentally friendly refrigerant is R134a. Thus, R134a, Tetrafluoroethane refrigerant is selected for the project work.

\section{Compressor selection}

Different kinds of compressors can be used for operation of the refrigeration cycle. Centrifugal compressors are generally used for large scale applications, where the refrigeration capacities exceed
$400 \mathrm{~kW}$. Likewise, reciprocating compressors are not very suitable when there is moisture present in the refrigerant. Scroll compressors are suitable for producing refrigeration capacities around $15 \mathrm{~kW}$. The selection of an appropriate compressor has enough merit to be considered as a stand alone paper and thus hasn't been described in this work.

\section{Evaporator and condenser selection}

Both evaporator and condenser equipment of the refrigeration cycle are heat exchangers. In the evaporator, refrigerant exchanges heat with the chilled water and whereas in the condenser, the refrigerant exchanges heat with the cooling water. Either a double pipe heat exchanger or a shell and tube heat exchanger is suitable for the given application. Since the required rate of heat transfer is large in both the evaporator and condenser a shell and tube heat exchanger is considered for the given application.

\section{Basic design of the cooling system}

The cooling system is intended to cool air by using chilled water. The basic design of a cross flow heat exchanger, the refrigeration cycle to provide the chilled water, the basic design of evaporator and condenser equipment were all considered in this work. Further, an analytical model was developed to partially simulate the functioning of the cooling system. In the development of the basic design of the heat exchanger equipment, performance charts were developed. Performance charts describe the performance of the heat exchanger in terms of significant dimensionless parameters. The charts report the heat exchanger effectiveness in terms of capacity rate ratio and number of transfer units. Capacity rate ratio and number of transfer units encompass the physical, the thermal and material characteristics of the heat exchanger. Likewise, they also account for flow configuration and fouling. In the design of any heat exchanger, it is very essential to develop the equipment such that it delivers the required heat transfer and yet is of light-weight, cheap, occupies less space, easy to manufacture, easy to maintain, consumes less material, etc. The parameter NTU accounts for all of the above-mentioned characteristics. Therefore, in the development of the heat exchanger, it is first essential to optimize the NTU and thereafter the detailed design of the heat exchanger can be developed.

Considering performance charts as described from Figures (6) through (16) and Figures (22) through (24), it can be clearly seen that increasing NTU indefinitely doesn't enhance the heat transfer, or in other words the heat exchanger effectiveness. From the basic principles, it could be assumed that increasing the surface area (or 
NTU, as NTU is a function of heat exchanger surface area) increases the rate of heat transfer. However, by considering the performance charts, it can be clearly seen that increasing the surface area increases heat transfer only until a certain limit. Beyond that threshold limit, increasing the surface area or in other words, NTU is useless as the heat exchanger effectiveness becomes almost constant thereafter. A heat exchanger having a lower NTU than the required will not deliver the required heat transfer and likewise, a heat exchanger having a NTU more than the required will have more material, more weight and shall most certainly incur additional cost. Hence, selecting or optimizing the NTU is an important activity in the design of the heat exchanger.

This work considered the development of performance charts for both cross flow and shell and tube heat exchangers. For the cross flow heat exchanger, Domingos approach [3] was employed in the development of performance charts. Likewise, since evaporator and condenser equipment are shell and tube heat exchangers, performance charts were also developed for those heat exchangers by using explicit relations provided in [12]

Using the equations presented, an analytical model was developed in the design of the cooling system. The model helped to develop the basic design for the cross flow heat exchanger, the design of the refrigeration cycle, the basic design for the evaporator and the condenser equipment. Figure 26 describes the basic design of the cooling system.

\begin{tabular}{|c|c|c|c|}
\hline \multicolumn{2}{|c|}{ BASIC DESIGN OF CROSS FLOW HX } & \multicolumn{2}{|c|}{ BASIC DESIGN OF REFRIGERATION CYCLE } \\
\hline Item & Description & Item & Description \\
\hline Number of trans fer units, NTU & 1.2 & Refrigerant & R134a \\
\hline Capacity rate ratio, $\mathrm{C}_{x}$ & 0.75 & By pass factor, BP & 0.2 \\
\hline Heat exchanger effectiveness, $\varepsilon$ & 0.63 & Apparatus dew point temperature, ADP & $9.025^{\circ} \mathrm{C}$ \\
\hline F low configuration & Counter & Evaporator temperature & $8.93^{\circ} \mathrm{C}$ \\
\hline External fluid & Air & Evaporator pressure & 4 bar \\
\hline Tube side fluid & Chilled water & Condenser temperature & $52.43^{\circ} \mathrm{C}$ \\
\hline Mass flow rate of air & $4.8 \mathrm{~kg} / \mathrm{s}$ & Condenser pressure & 14 bar \\
\hline Mass flow rate of chilled water & $1.5 \mathrm{~kg} / \mathrm{s}$ & Mass flow rate of refrigerant & $0.30 \mathrm{~kg} / \mathrm{s}$ \\
\hline Air inlet tempreture & $22.4^{\circ} \mathrm{C}$ & Compressor power & $13 \mathrm{hp}$ \\
\hline Required air discharge tempreture & $14.6^{\circ} \mathrm{C}$ & Evaporator load & 11 ton \\
\hline Chilled water inlet temperature & $10^{\circ} \mathrm{C}$ & Condenser bad & 13 ton \\
\hline Chilled water discharge temperature & $15.9^{\circ} \mathrm{C}$ & Cooling tower capacity & 13 ton \\
\hline \multirow[t]{2}{*}{ Cross flow heat exchanger load } & $37.6 \mathrm{~kW}$ & Mass flow rate of cooling water & $2.8 \mathrm{~kg} / \mathrm{s}$ \\
\hline & & COP & 4.2 \\
\hline \multicolumn{2}{|c|}{ BASIC DESIGN OF CONDENSER } & \multicolumn{2}{|c|}{ BASIC DESIGN OF EVAPORATOR } \\
\hline Item & Description & Item & Description \\
\hline Number of trans fer units, NTU & 0.5 & Number of transfer units, NTU & 1.75 \\
\hline Capacity rate ratio, $\mathrm{C}_{\tau}$ & o & Capacity rate ratio, $\mathrm{C}_{x}$ & o \\
\hline Heat exchanger effectiveness, $\varepsilon$ & 0.31 & Heat exchanger effectiveness, $\varepsilon$ & 0.78 \\
\hline Flow configuration & NA & F low configuration & NA \\
\hline External fluid & R134a & External fluid & R134a \\
\hline Tube side fluid & Cooling wates & Tube side fluid & Chilled water \\
\hline Mass flow rate of refrigerant & $0.30 \mathrm{~kg} / \mathrm{s}$ & Mass flow rate of refrigerant & $0.30 \mathrm{~kg} / \mathrm{s}$ \\
\hline Mass flow rate of cooling water & $2.8 \mathrm{~kg} / \mathrm{s}$ & Mass flow rate of chilled water & $2.3 \mathrm{~kg} / \mathrm{s}$ \\
\hline Condenser temperature & $52.43^{\circ} \mathrm{C}$ & Evaporator temperature & $8.93^{\circ} \mathrm{C}$ \\
\hline Condenser pressure & 14 bar & Evaporator pressure & 4 bar \\
\hline
\end{tabular}

Fig. 26: Basic Design of the Cooling System.

\section{Conclusions}

The paper concentrates on the development of a basic cooling system to cool the "quench" air used in the production of nylon 6,6 polymer. The air is pretreated in an air washer and is available at $72^{\circ} \mathrm{F}$. The air is required to be cooled to $58^{\circ} \mathrm{F}$. The heart of the cooling system is the refrigeration cycle that produces chilled water. Chilled water is used as a secondary refrigerant and is used for cooling air to the desired level.

As described in Figure 1, the cooling system is sub divided into three subsystems, such as the quench system, the main refrigeration system and a cooling water system. The main component of the quench system is the cross flow heat exchanger. The basic design of the cross flow heat exchanger was developed in this work. Therein, performance charts using Domingos approach [3] were developed to come up with the basic design of the heat exchanger. Using performance charts, the required number of transfer units (NTU) and capacity rate ratio $(\mathrm{Cr})$ were estimated. These two parameters can readily be extrapolated to complete design for the cross flow heat exchanger. This has been described in detail in [1] During the basic design of the cross flow heat exchanger, both parallel and counter flow configurations were considered. Therein, it was seen that the required NTU for the counter cross flow heat exchanger was lower than that of a parallel cross flow heat exchanger. This means that the counter cross flow heat exchanger will require smaller surface area, which means lower capital cost, lighter weight, etc.

Likewise, a refrigeration cycle was developed to provide chilled water for the quench system. A standard, readily available and an environmentally refrigerant was chosen for the application. The operating parameters for evaporator, condenser and compressor were estimated. It must be recognized that evaporator and condenser are heat exchangers where the refrigerant exchanges heat with the other fluids. Typically, evaporator and condenser are all shell and tube heat exchangers. Therefore, in the design of evaporator and condenser equipment, performance charts were developed for shell and tube heat exchangers. Since the refrigerant undergoes phase change in both these equipment, the choice of flow configuration is not of importance. Using performance charts, the basic design of the evaporator and condenser equipment were estimated as well. From the basic design the detailed design can be devloped by using the techniques presented in [2] and [12]. As mentioned, the required pumping system for the cross flow heat exchanger and for the condenser cooling water are not detailed in this work. The techniques presented in [11] can be readily employed in the development of the pumping system. 
The performance charts presented in this work will be valuable for design engineers during the initial development of the heat exchanger. Estimating NTU is a crucial activity during the development of any heat exchanger equipment. The process is usally time consuming as it requires detailed calculations. Performance charts will guide the engineers in quickly estimating the required NTU for the heat exchanger. Likewise, NTU is a direct function of heat exchanger surface area and it accounts for all the physical and thermal properties of the heat exchanger. Thus choosing the right NTU will help in optimizing the capital cost of the heat exchanger. Likewise, capacity rate ratio has a direct impact on the operating cost of the heat exchanger as it is a function of mass flow rate of the fluids. Therefore, these charts will certainly support in the design process of heat exchanger. In-addition all cooling systems must be developed such that it can handle varying refrigeration loads. When the refrigeration load varies, the operating set points of the heat exchanger will also vary. The field engineers can use performance charts as a guide and can estimate ahead of time whether the equipment is capable of handling such variations.

\section{References}

[1] Kays, W. M., and London A. L., Compact Heat Exchangers, $3^{\text {rd }}$ Ed., McGraw-Hill, New York, 1984.

[2] Rohsenow, W. M., Heat Exchangers - Basic Methods, in Heat Exchangers Thermal-Hydraulic Fundamentals and Design, Hemisphere Publishing Corporation, Washington D.C., 1982.

[3] Domingos, J. D., Analysis of Complex Assemblies of Heat Exchang ers, Int. J. Heat Mass Transfer, Vol. 12, pp. 537-548, 1969. https://doi.org/10.1016/0017-9310(69)90037-4.

[4] Pignotti, A. and Shah, R. K., Effectiveness-number of transfer units relationships for heat exchanger complex flow arrangements, Int. J. Heat Mass Transfer, Vol. 35, No. 5, pp. 1275-1291, 1992. https://doi.org/10.1016/0017-9310(92)90184-T.

[5] Shah, R. K. and Pignotti, A., Thermal Analysis of Complex Crossflow Exchangers in Terms of Standard Configurations, J. Heat Transfer, Vol. 115, pp. 353-359, 1993 https://doi.org/10.1115/1.2910686.

[6] Mott, J. E. and Mills, R. R., Computerized Design of a Minimum Cost Heat Exchanger, ASME Paper 72-HT-26, 1972.

[7] Genic, S. B., Jacimovic, B. M., and Genic, V. B., Economic optimization of pipe diameter for complete turbulence, Energy and Buildings, Vol. 45, pp. 335-338, 2012. https://doi.org/10.1016/j.enbuild.2011.10.054.

[8] Kovaric, M., Optimal Heat Exchangers, J. Heat Transfer, Vol. 111, pp. 287-293, 1989. https://doi.org/10.1115/1.3250676

[9] Ramananda Rao, K., Shrinivasa, U., and Srinivasan, J., Synthesis of Cost-Optimal Shell-and Tube Heat Exchangers, Heat Transfer Engineering, Vol. 12, No. 3, pp. 47-55, 1991 https://doi.org/10.1080/01457639108939756.

[10] Caputo, A. C., Pelagagge, M. P., and Salini, P., Heat Exchanger Design Based on Economic Optimization, Paper CIT06-0387, ENCIT 2006 -ABCM, Curitiba, Brazil, 2006.

[11] Silaipillayarputhur, K., Al-Muhaysh, K., and Al Yahya, O., 2016 "Design of a Dowtherm A Pumping System", International Journal of Applied Engineering Research, ISSN: 0973-4562, Volume 11, Issue 1, page 265-272, Research India Publications, India

[12] Bergman, T. L., Lavine, A. S., Incropera, F. P., and DeWitt, D. P., Fundamentals of Heat and Mass Transfer, $7^{\text {th }}$ Ed., John Wiley, Hoboken, NJ, 2011.

[13] Campbell, J.M., Gas Conditioning and Processing, Volume 2: The Equipment Modules, 9th Edition, 2nd Printing, Editors Hubbard, R. and Snow-McGregor, K., Campbell Petroleum Series, Norman, Oklahoma, 2014 